\title{
Expression of CIDE proteins in clear cell renal cell carcinoma and their prognostic significance
}

\author{
Ming Yu $\cdot$ Hui Wang $\cdot$ Jun Zhao $\cdot$ Yuan Yuan $\cdot$ \\ Chao Wang · Jing Li • Lijun Zhang • \\ Liying Zhang • Qing Li · Jing Ye
}

Received: 15 November 2012/Accepted: 23 February 2013/Published online: 11 March 2013

(C) The Author(s) 2013. This article is published with open access at Springerlink.com

\begin{abstract}
Clear cell renal cell carcinoma (ccRCC) is the major and aggressive subtype of renal cell carcinoma. It is known to derive its histologic appearance from accumulation of abundant lipids and glycogens. The cell deathinducing DFF45-like effector (CIDE) family has been characterized as the lipid droplet proteins involved in the metabolism of lipid storage droplets. The purpose of this study was to evaluate the expression of CIDE proteins in ccRCC cells and to investigate their prognostic significance. We examined consecutive patients with sporadic ccRCC, who underwent nephrectomy, to measure their mRNA and protein expression of CIDE proteins. We found that Cidec and ADRP expression were significantly upregulated in ccRCC, compared with normal kidney tissues. Cideb was down-regulated. We also found that Cideb was expressed more in low-grade ccRCC than in high-grade tumors. To further clarify the relationship between Cideb expression and patient prognosis, we evaluated $57 \mathrm{ccRCC}$ patients followed up for 120 months. Reduced ccRCC
\end{abstract}

Ming Yu, Hui Wang and Jun Zhao Contributed equally to this study.

Electronic supplementary material The online version of this article (doi:10.1007/s11010-013-1605-y) contains supplementary material, which is available to authorized users.

M. Yu $\cdot$ H. Wang $\cdot$ J. Zhao $\cdot$ Y. Yuan $\cdot$ C. Wang $\cdot$ J. Li $~$

L. Zhang $\cdot$ L. Zhang $\cdot$ Q. Li $(\bowtie) \cdot$ J. Ye $(\bowtie)$

The Department of Pathology, Xijing Hospital, Fourth Military

Medical University, Xi'an, Shaanxi, China

e-mail: liqing@fmmu.edu.cn

J. Ye

e-mail: yejing@fmmu.edu.cn

M. Yu

The Department of Ultrasonography, Xijing Hospital, Fourth

Military Medical University, Xi'an, Shaanxi, China
Cideb expression was associated with a higher Fuhrman nuclear grade. Patients with high Cideb expression had better overall survival rate than those with low expression $(p<0.05)$. Cideb expression was an independent predictor of survival $(p=0.001)$. Although the biologic function of Cideb in ccRCC remains unknown, the expression level of Cideb might be a novel predictor of prognosis in ccRCC.

Keywords Cideb - Lipid droplet $\cdot$ Clear cell renal cell carcinoma $\cdot$ Metabolism

\section{Introduction}

Renal cell carcinoma (RCC) is the most common malignant tumor in the adult kidney, accounting for about $3 \%$ of human malignancies [1]. On the basis of current genetic knowledge and histologic findings, RCC can be classified into at least four major subtypes: clear cell (ccRCC), papillary, chromophobe, and collecting duct carcinoma [2, 3]. Among them, ccRCC represents the most common subtype $(83 \%)$ [4]. Unfortunately, ccRCCs show an extremely variable clinical course, which cannot be predicted. Additional prognostic markers are needed for a more accurate determination of the prognosis and the improvement of therapeutic strategies.

Clear cell RCC is characteristically of a bright golden color, and the clear appearance of tumor cells is due to cellular storage of lipid and glycogen [5-7]. Some epidemiologic studies have shown that obesity is a risk factor for RCC $[8,9]$. In general, previous studies suggested that obese patients (with a BMI $>30 \mathrm{~kg} / \mathrm{m}^{2}$ ) were associated with a high proportion of ccRCC [10-12]. It is apparent that ccRCC cells possess some abnormalities in the metabolism of lipids and glycogen. 
The cell death-inducing DFF45-like effector (CIDE) family has been characterized as the crucial lipid droplet (LD) proteins involved in the formation and stabilization of lipid storage droplets $[13,14]$. The CIDE family is composed of three members: Cidea, Cideb, and Cidec (CIDE-3 or Fat-specific protein 27) [14]. Previous studies have suggested that Cidea is predominantly expressed in brown adipose tissue [15], and mammary glands [16], while Cidec is expressed at high levels in white adipose tissue [17]. Cideb is strongly expressed in the liver and kidney, in both mice and humans $[18,19]$.

The presence of abundant LDs suggests that LD proteins are associated with the development of ccRCC. It has been reported adipose differentiation-related protein (ADRP), a LD protein, is highly up-regulated both at the transcriptional and protein levels in ccRCC [20]. The role of CIDE family proteins has not been evaluated. In this study, we measured the CIDE family protein expression in ccRCC using real-time quantitative PCR and western blot. CIDE family expression levels were correlated with the malignancy of ccRCC. We examined 57 consecutive patients with ccRCC to evaluate Cideb expression level in primary tumors and its prognostic significance.

\section{Materials and methods}

Tissue and antibody

Clear cell RCC and corresponding normal kidney samples were collected from patients who underwent nephrectomy at the Fourth Military Medical University and its affiliated hospitals. Patients did not receive any preoperative therapy. All specimens were snap-frozen with liquid nitrogen and stored at $-80{ }^{\circ} \mathrm{C}$ for nucleic acid and protein extraction. The histologic slides, stained with hematoxylin and eosin, were reviewed to confirm nuclear Fuhrman grading. Written informed consent was obtained for studying gene expression. The study protocol was approved by the institutional ethics committee. The case series consisted of 10 fresh ccRCC tumors and 10 fresh normal renal tissue specimens obtained from 10 patients. These tumors were classified according to the Fuhrman's nuclear system. Five patients had low grade tumors (grade 1 and grade 2 ) and five high grade tumors (grade 3 and grade 4). 57 pathologically confirmed sporadic ccRCC patients, diagnosed from May 2001 to December 2003, were also identified: 15 tumors were grade 1,18 grade 2,16 grade 3 , and 8 grade 4 . The mean follow-up period was 52 months (range: $2-116$ ). The mean tumor size was $6.47 \pm 2.97 \mathrm{~cm}$ (Mean \pm standard deviation). The mean patient age was 59 years (range 32-79). The clinicopathological data are summarized in Table 1. Rabbit anti-Cidea and anti-Cidec polyclonal antibodies were donated by Dr. Peng Li (Department of Biological Sciences and Biotechnology, Tsinghua University, Beijing, China). Mouse anti-Cideb monoclonal was generated by Dr Boquan Jin (Department of Immunology, the Fourth Military Medical University, Shaanxi, China). Anti-GAPDH and anti- $\beta$-tubulin antibody were purchased from Abcam (Cambridge, MA, USA).

\section{Oil Red O staining}

The frozen sections of fresh renal tissues and ccRCC samples were stained with Oil Red O. In brief, cryopreserved tissues were cut into $10-\mu \mathrm{m}$ sections, and fixed in $10 \%$ formalin for $5 \mathrm{~min}$. Sections were washed in $60 \%$ isopropanol for $2 \mathrm{~min}$, then incubated in Oil Red O (Sigma, USA) working solution for $15 \mathrm{~min}$. The stained tissues were washed using $60 \%$ isopropanol, and then water, to remove residual staining. Slides were counterstained in hematoxylin for $2 \mathrm{~min}$. The slides were mounted with aqueous mounting media and glycerin jelly, and examined under light microscopy.

\section{Electron microscopy}

The tissues for electron microscopy were fixed in $2.5 \%$ cold glutaraldehyde overnight, at $4{ }^{\circ} \mathrm{C}$. Tissues were then rinsed for $1 \mathrm{~h}$ in cold phosphate buffer solution (PBS, $0.1 \mathrm{M}, \mathrm{pH}$ 7.4) and fixed in $1 \%$ osmium tetroxide for $1 \mathrm{~h}$. Tissues underwent gradient acetone dehydration, were Epon 812 resin embedded, and ultra-thin sections $(70 \mathrm{~nm})$ were cut onto slides. Sections were stained with uranyl acetate and lead citrate for JEM-1011 transmission electron microscope observation.

RNA isolation, cDNA synthesis, and quantitative PCR analysis

RNA was isolated from 10 frozen tumors and 10 normal renal specimens, using Trizol reagent (invitrogen, USA), according to the manufacturer's instructions. RNA was quantified using the Nanodrop ND-2000 spectrophotometer (Nano-Drop Technologies, Rockland, DE, USA). Total RNA was reverse transcribed using Super-Script II

Table 1 Clinical and histopathological characteristics

\begin{tabular}{|c|c|c|c|c|c|}
\hline \multirow[t]{2}{*}{ Fuhrman grade } & \multirow[t]{2}{*}{ Patient (\%) } & \multicolumn{2}{|c|}{ Gender } & \multicolumn{2}{|c|}{ Age (years) } \\
\hline & & Male & Female & Median & Range \\
\hline Grade 1 & $15(14 \%)$ & 5 & 3 & 53 & $46-62$ \\
\hline Grade 2 & $18(48 \%)$ & 21 & 8 & 58 & $47-73$ \\
\hline Grade 3 & $16(23 \%)$ & 11 & 3 & 56 & $42-71$ \\
\hline Grade 4 & $8(15 \%)$ & 6 & 3 & 58 & $51-75$ \\
\hline
\end{tabular}


Table 2 Primer sequences

\begin{tabular}{llr}
\hline Gene & Primer sequences & Genbank \\
\hline Cidea & Forward: CATGTATGAGATGTACTCCGTGTC NM_001279.3 & Reverse: GAGTAGGACAGGAACCGCAG \\
& Forward: AGCCAAAGCATTGGAGACCCTACT & NM_014430.2 \\
Cideb & Reverse: TCTGACCAGACTGCAACACCATCA & NM_022094.2 \\
Cidec & Forward: TTGATGTGGCCCGTGTAACGTTTG & NM_001122.2 \\
ADRP/perilipin2 & Reverse: AAGCTTCCTTCATGATGCGCTTGG & Forward: CTGAGCACATCGAGTCACATACTCT \\
GAPDH & Reverse: GGAGCGTCTGGCATGTAGTGT & Fo2046.3 \\
& Forward: GAAGGTGAAGGTCGGAGTC & \\
\hline
\end{tabular}

(TaKaRa, Japan). Primers were designed from the sequence of the human cDNAs, and primer sequences are listed in Table 2. Quantitative PCR was performed using the Steponereal-time PCR system (Applied Biosystems) in a total volume of $25 \mu \mathrm{l}$ with SYBR green (TaKaRa, Japan). cDNAs were serially diluted to obtain five standard solutions that were used in the PCR reaction to generate the reference data. Stepone software was used to generate the reference curve. In each experiment, at least three independent reactions were performed to obtain the mean. Samples were normalized by dividing by the number of copies of GAPDH mRNA.

\section{Immunohistochemistry}

We had 57 pathologically confirmed ccRCC patients with long-term follow-up, and obtained the patient's formalinfixed paraffin-embedded specimens. All samples were dewaxed in xylene three times for 5-10 min, rehydrated in descending alcohol gradients for $5 \mathrm{~min}$, and blocked for endogenous peroxidase $\left(3 \% \mathrm{H}_{2} \mathrm{O}_{2}\right.$ in $80 \%$ methanol) for $20 \mathrm{~min}$. Antigen retrieval was performed using two treatments in $10 \mathrm{mM}$ sodium citrate in a microwave for $15 \mathrm{~min}$. After blocking non-specific antigen with normal goat serum for $30 \mathrm{~min}$, the slides were incubated with mouse anti-Cideb monoclonal antibody (dilution at 1:200) overnight at $4{ }^{\circ} \mathrm{C}$. Slides were incubated with 100-200 $\mu$ l of labeled secondary antibody for $30 \mathrm{~min}$ at room temperature. Visualization was performed using diaminobenzidine (DAB). The slides were counterstained in hematoxylin for $2 \mathrm{~min}$, dehydrated in ethanol, and mounted. The Cideb expression was evaluated in ccRCC. Low expression was considered as absence or $<20 \%$ expression in RCC, and high expression was considered as $\geq 20 \%$ expression in RCC.

\section{Western blot}

From 10 frozen tumor tissues and 10 normal renal tissues, total samples were separated in a $10 \%$ SDS-PAGE gel and transferred onto a Immobilon-Polyvinylidene fluoride (PVDF) membrane (Millipore Corporation, MA, USA). After blocking with $5 \%$ skimmed milk, the membrane was incubated with mouse anti-Cideb monoclonal antibody (dilution at 1:2,000), rabbit anti-Cidea antibody (dilution at $1: 1,000)$, rabbit anti-Cidec (dilution at 1:4,000), or mouse anti-GAPDH (dilution at 1:1,000). After washing, membranes were incubated for $1 \mathrm{~h}$ with a 1:5,000 dilution of peroxidase-conjugated goat anti-rabbit or anti-mouse immunoglobulin (Santa Cruz Biotechnology, Santa Cruz, CA) and expression characterized by chemiluminescence.

Statistical analyses

Statistical analysis was performed using the SPSS 13.0 software. Statistical analyses were performed with independent samples for $t$ test and cox proportional hazards regression model. $p$ value $<0.05$ was considered as statistically significant.

\section{Results}

Frequent lipid droplet accumulation in ccRCC

In the light microscope, numerous large Oil Red O-positive, big LDs were visible in ccRCC cells (Fig. 1b), while normal renal tissues contained significantly fewer LDs (Fig. 1a). Similarly, electron microscopy analysis further confirmed the presence of abundant LDs in the samples of clear cell RCC (Fig. 1c).

mRNA and protein levels of CIDE family in ccRCC

We determined CIDE protein and mRNA expression and correlated it with ccRCC clinicopathological parameters. As shown in Fig. 2a, the mRNA level of Cidec was increased nearly sixfold in renal tumor tissues compared 


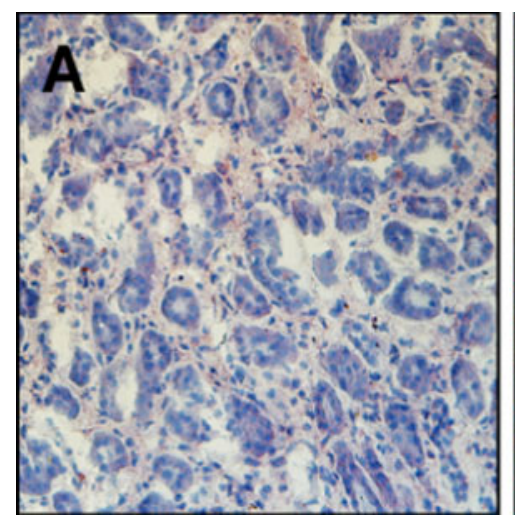

Fig. 1 Increased lipid droplets in ccRCC. Images of renal sections stained with Oil Red $\mathrm{O}$ from normal renal and $\operatorname{ccRCC}(\mathbf{a}, \mathbf{b})$. The red color spots in Oil Red O staining represent the lipid droplets in the

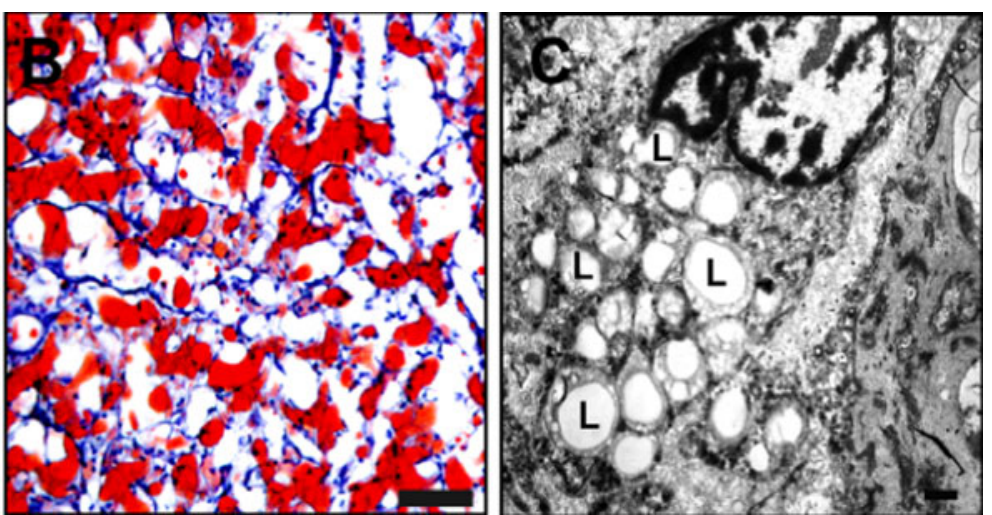

ccRCC(B). scale bars $50 \mu \mathrm{m}$. $\mathbf{c}$ transmission electron micrograph of renal sections from $\mathrm{ccRCC}$ (original magnification $\times 5000)$. L,lipid droplets. (Color figure online)
Fig. 2 a RT-PCR results of CIDE family in ccRCC and adjacent noncancerous tissues. b Expression of CIDE protein in ccRCC and adjacent noncancerous tissues. $\beta$-tubulin was used as an internal control
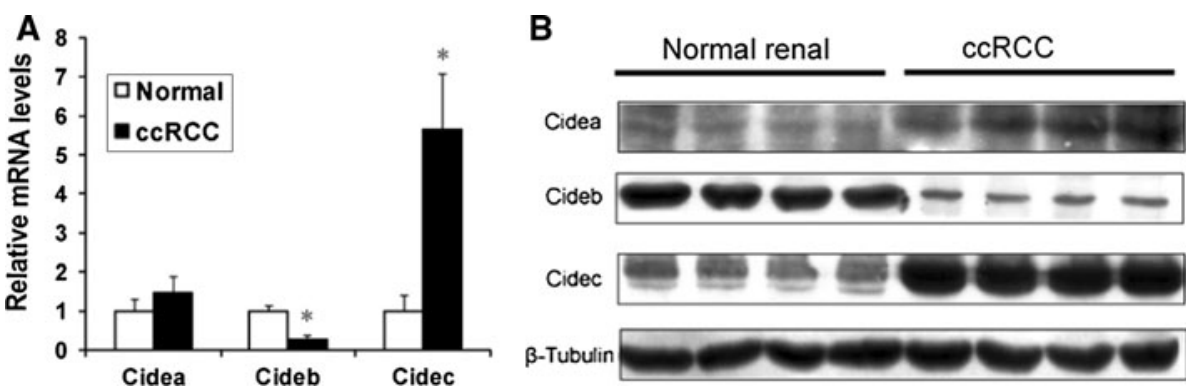

with normal renal tissues $(p<0.001)$. In contrast, Cideb mRNA expression in ccRCC decreased about threefold $(p<0.001)$ in comparison with normal renal tissue. mRNA expression of Cidea in ccRCC increased about 1.46-fold ( $p=0.643$ ). Moreover, ADRP, a PAT member, had about 20 -fold higher expression $(p<0.001)$ in ccRCC, compared with the normal renal tissue (data not shown). Similarly, the western blot showed that Cideb protein expression was significantly lower in ccRCC, compared with adjacent normal renal tissues. Cidec protein expression was increased in ccRCC, compared with adjacent normal renal tissues (Fig. 2b). There was no obvious difference in the expressions of Cidea. These results demonstrate that CIDE proteins, especially Cideb and Cidec, correlated with LD accumulation in ccRCC.

\section{Correlation of Cideb expression with ccRCC grading}

It has been previously demonstrated that ccRCC with lower nuclear grade shows a typical "clear-cell" appearance. As nuclear grade increases, the cytoplasm becomes more eosinophilic and its "clear-cell" character diminishes [21]. Based on nuclear Fuhrman grading, we divided the ccRCC into two groups: low grade (Fuhrman grade 1 and 2) and high grade (Fuhrman grade 3 and 4 ). When comparing real time-PCR expressions of the CIDE family between low- grade and high-grade tumors (Fig. 3a), a significant difference was found only in Cideb mRNA expression ( $p=0.018$ ); Cideb mRNA expression was higher in lowgrade tumors than in high-grade tumors. There were no significant differences in Cidea and Cidec expressions ( $p=0.217$ and 0.386, respectively). Similar results were found by western blot (Fig. 3b). These data suggest that Cideb is correlated with ccRCC grade.

Correlation of Cideb expression with the prognosis in ccRCC patients

To further demonstrate the prognostic significance of $\mathrm{Ci}$ deb in ccRCC, immunohistochemistry (IHC) was used to detect the expression level of Cideb in 57 patients with ccRCC. Cideb expression was diffuse and strong staining in normal renal tubular epithelial cells (Fig. 4a). In ccRCC, the cytosolic expression level of Cideb was obviously lower compared with normal renal tissues (Fig. 4b-d). Cideb immunostaining score decreased with the increasing Fuhrman nuclear grade. Fuhrman nuclear grade 1 and grade 2 ccRCC demonstrated high Cideb expression $(96.7 \%, 30 / 31)$, while Fuhrman nuclear grade 3 and grade 4 ccRCC had low expression $(92.3 \%, 24 / 26)$.

To assess the prognostic significance of Cideb expression, we divided the ccRCC patients into two groups: 
Fig. 3 a Relative mRNA expression by quantitative realtime PCR analysis. ${ }^{*} p=0.018$. The data are shown as mean \pm SE. b Western blot analysis of low grade and high grade ccRCC
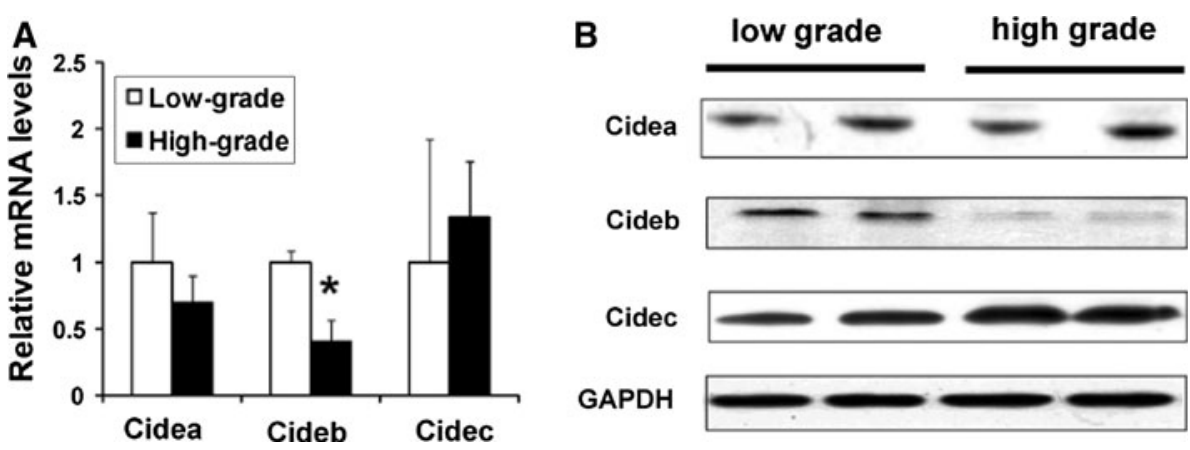
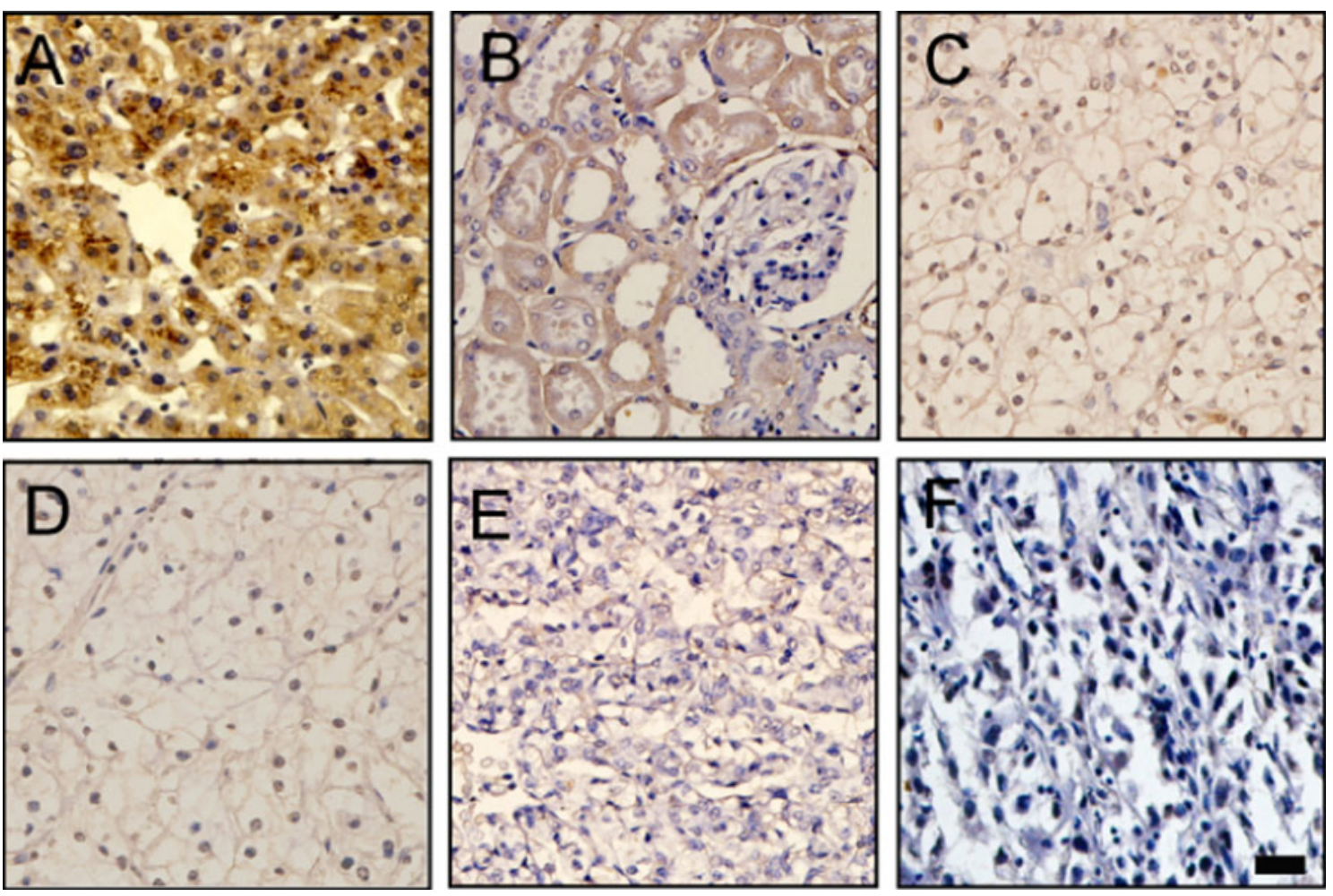

Fig. 4 Correlation between Cideb immunostain and Fuhrman nuclear grade in clear cell RCC. a liver(positive control) b normal renal $\mathbf{c}$ grade 1 ccRCC d grade 2 ccRCC e grade 3 ccRCC $\mathbf{f}$ grade 4 ccRCC (original magnification $\times 400$ )

those with high Cideb expression ( $>20 \%$ ), and those with low Cideb expression (absence or $<20 \%$ positive cells). Univariate analysis revealed a significantly shorter progression-free survival for patients with low Cideb expression (RR, 2.906; $95 \%$ CI, 1.377-6.132; $p=$ 0.005). To evaluate whether low Cideb expression in ccRCC was an independent predictor of overall survival, a multivariate analysis was performed using the Cox proportional hazard test. Low Cideb expression was an independent prognostic factor for survival $(p=0.001$, Table 3). A Kaplan-Meier curve showed that patients with low Cideb expression in their ccRCC had significantly shorter cancer-specific survival than those with high expression. This difference was apparent very early during follow up (Fig. 5, $p=0.005$ ).

\section{Discussion}

It is well known that the clear appearance of tumor cells results from cellular storage of lipid and glycogen [7]. Clearcell RCC with lower nuclear grade show a typical "clearcell" appearance. However, as nuclear grade increases, the "clear-cell" character diminishes, and the number of LD decreases. Some LD proteins (such as ADRP, adipose differentiation-related protein or adipophilin) have been shown to have a role in clear-cell renal carcinoma differentiation [20]. The microvessel density in ccRCC tends to decrease as the tumor grade increases $[22,23]$.

The CIDE family regulates lipid metabolism and plays an important role in the development of metabolic disorders including obesity, insulin resistance, and hepatic 
Table 3 Univariate and multivariate analyses of cancer-specific survival in 57 patients with ccRCC

\begin{tabular}{|c|c|c|c|c|c|c|}
\hline \multirow[t]{2}{*}{ Characteristics } & \multicolumn{3}{|c|}{ Univariate analysis } & \multicolumn{3}{|c|}{ Multivariate analysis } \\
\hline & $\mathrm{RR}$ & $95 \% \mathrm{CI}$ & $P$ & $\mathrm{RR}$ & $95 \% \mathrm{CI}$ & $P$ \\
\hline Age $(>60 / \leq 60)$ & 2.365 & $1.131-4.977$ & 0.022 & 2.881 & $1.361-6.097$ & 0.006 \\
\hline Gender (male/female) & 0.403 & $0.140-1.157$ & 0.091 & $\mathrm{X}$ & & \\
\hline Cideb expression (low/high) & 2.906 & $1.377-6.132$ & 0.005 & 3.444 & $1.612-7.356$ & 0.001 \\
\hline Tumor size, cm $(\geq 6 /<6)$ & 1.361 & $0.664-2.791$ & 0.400 & $X$ & & \\
\hline
\end{tabular}

$R R$ risk ratio, $95 \% C I 95 \%$ confidence interval

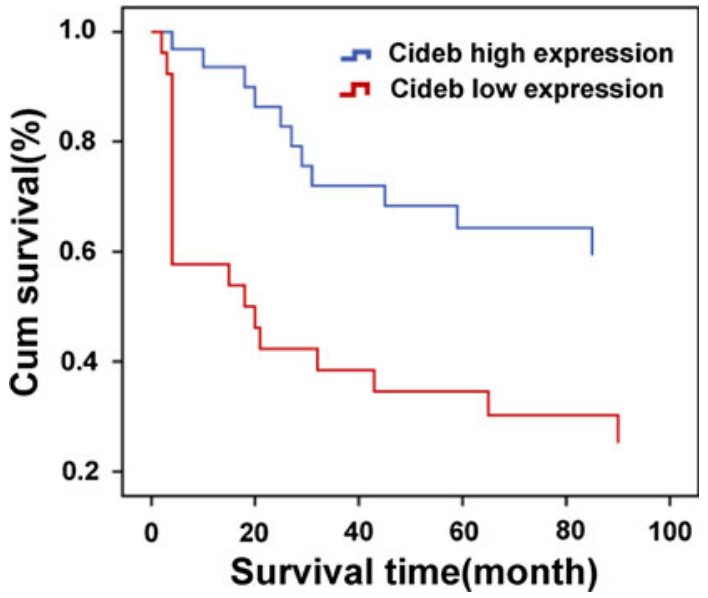

Fig. 5 The association of survival with different levels of Cideb expression is illustrated in $57 \mathrm{ccRCC}$ patients $(p<0.01)$. Patients with high expression of Cideb had longer survival than those with low expression of Cideb

steatosis [15, 17, 24-26]. We identified CIDE family members which were associated with LD storage in ccRCC. Compared with normal kidney tissues, there was significant up-regulation of Cidec and down-regulation of Cideb in ccRCC, but little change in Cidea. Cidea was a BAT-specific marker, while Cidec was most highly expressed in WAT [14]; thus, the different ccRCC expression levels suggest that the lipid storage in ccRCC is more related to WAT than BAT. In addition, we observed that the mRNA levels of Cidec in high-grade ccRCC was slightly higher than that in low-grade ccRCC, but the protein levels of Cidec were similar. Several possibilities might be involved in the regulation of Cidec, such as protein degradation, transcriptional regulation, etc.. Normally, Cideb is expressed at a high level in liver and kidney tissues [18]. Although CIDE proteins have been shown to regulate the biosynthesis and storage of LDs in adipocytes and hepatocytes [14, 18, 25], the function of CIDE proteins in ccRCC has not been determined.

It is well known that ccRCC contains abundant lipids in the cytoplasm, including triglycerides, cholesterol esters, and phospholipids. These lipids impart the typical gross "yellow" appearance $[1,21,27]$. We confirmed the abundant lipid accumulation in ccRCC using Oil Red O and electron microscopy. We found that Cidec protein expression significantly increased, while Cidea expression did not change in ccRCC, compared with normal renal tissue. The different Cidea and Cidec expression levels in ccRCC suggest that lipid storage in ccRCC is more related to WAT than BAT. The down-regulation of Cideb in ccRCC suggests it may prevent the formation of ccRCC cells. We speculated that Cideb could promote lipid secretion in renal cells, similar to its functions in liver cells [18]. These data strongly suggest that the decreasing level of Cideb protein is implicated in lipid uptake and storage in clear-cell RCC. Moreover, Cideb expression levels were likely to reflect microscopic morphologic appearances and the degree of malignancy of clear-cell RCC.

Using IHC, we found that the expression of Cideb in both grade 3 and grade 4 were lower than that in grade 1 and grade 2, while the protein level of Cideb in grade 1 were similar to grade 2. The differences of Cideb in the ccRCC were similar to ADRP [28]. The higher Fuhrman nuclear grade was associated with poor prognosis [29]. Multivariate analysis confirmed that reduction in the expression of Cideb was an independent prognostic factor related to shorter progression-free survival $(p=0.001)$. Thus, low expression of Cideb might be applied as a novel prognostic marker. Collectively, these findings suggest that ccRCC has abnormal lipid metabolism. We observed that the expression of Cideb was largely decreased at both mRNA and protein levels in ccRCC. Our data indicate that the loss of Cideb expression is an important event in lipogenesis and progression of ccRCC.

The mechanism of abnormal lipid metabolism in ccRCC has not been fully elucidated. It is noteworthy that lipogenesis is part of the malignant process in RCC [30]. In this study, we have shown that low Cideb expression is correlated with higher nuclear grade of the ccRCC and poor clinical outcome. A further, larger study should be performed to extend and validate the precise mechanism by which Cideb regulates lipid metabolism and tumor progression in ccRCC. 
Acknowledgments This study was supported by National Natural Science Foundation of China (81070249, 31171132, 81100612, 81101752) and National Special Foundation for Key Drug Innovation of China (2009ZX09102-226).

Open Access This article is distributed under the terms of the Creative Commons Attribution License which permits any use, distribution, and reproduction in any medium, provided the original author(s) and the source are credited.

\section{References}

1. Motzer RJ, Bander NH, Nanus DM (1996) Renal-cell carcinoma. N Engl J Med 335:865-875

2. Kovacs G, Akhtar M, Beckwith BJ, Bugert P, Cooper CS, Delahunt B, Eble JN, Fleming S, Ljungberg B, Medeiros LJ, Moch H, Reuter VE, Ritz E, Roos G, Schmidt D, Srigley JR, Storkel S, van den Berg E, Zbar B (1997) The heidelberg classification of renal cell tumours. J Pathol 183:131-133

3. Storkel S, Eble JN, Adlakha K, Amin M, Blute ML, Bostwick DG, Darson M, Delahunt B, Iczkowski K (1997) Classification of renal cell carcinoma: workgroup no. 1. Union internationale contre le cancer (UICC) and the american joint committee on cancer (AJCC). Cancer 80:987-989

4. Cheville JC, Lohse CM, Zincke H, Weaver AL, Blute ML (2003) Comparisons of outcome and prognostic features among histologic subtypes of renal cell carcinoma. Am J Surg Pathol 27:612-624

5. Ericsson JL, Seljelid R, Orrenius S (1966) Comparative light and electron microscopic observations of the cytoplasmic matrix in renal carcinomas. Virchows Arch Pathol Anat Physiol Klin Med 341:204-223

6. Grignon DJ, Che M (2005) Clear cell renal cell carcinoma. Clin Lab Med 25:305-316

7. Rezende RB, Drachenberg CB, Kumar D, Blanchaert R, Ord RA, Ioffe OB, Papadimitriou JC (1999) Differential diagnosis between monomorphic clear cell adenocarcinoma of salivary glands and renal (clear) cell carcinoma. Am J Surg Pathol 23:1532-1538

8. Chow WH, Gridley G, Fraumeni JF Jr, Jarvholm B (2000) Obesity, hypertension, and the risk of kidney cancer in men. N Engl J Med 343:1305-1311

9. Bergstrom A, Hsieh CC, Lindblad P, Lu CM, Cook NR, Wolk A (2001) Obesity and renal cell cancer-a quantitative review. Br J Cancer 85:984-990

10. Donat SM, Salzhauer EW, Mitra N, Yanke BV, Snyder ME, Russo P (2006) Impact of body mass index on survival of patients with surgically treated renal cell carcinoma. J Urol 175:46-52

11. Lowrance WT, Thompson RH, Yee DS, Kaag M, Donat SM, Russo P (2010) Obesity is associated with a higher risk of clearcell renal cell carcinoma than with other histologies. BJU Int 105: $16-20$

12. Renehan AG, Tyson M, Egger M, Heller RF, Zwahlen M (2008) Body-mass index and incidence of cancer: a systematic review and meta-analysis of prospective observational studies. Lancet 371:569-578

13. Ducharme NA, Bickel PE (2008) Lipid droplets in lipogenesis and lipolysis. Endocrinology 149:942-949

14. Gong J, Sun Z, Li P (2009) CIDE proteins and metabolic disorders. Curr Opin Lipidol 20:121-126
15. Zhou Z, Yon Toh S, Chen Z, Guo K, Ng CP, Ponniah S, Lin SC, Hong W, Li P (2003) Cidea-deficient mice have lean phenotype and are resistant to obesity. Nat Genet 35:49-56

16. Wang W, Lv N, Zhang S, Shui G, Qian H, Zhang J, Chen Y, Ye J, Xie Y, Shen Y, Wenk MR, Li P (2012) Cidea is an essential transcriptional coactivator regulating mammary gland secretion of milk lipids. Nat Med 18:235-243

17. Toh SY, Gong J, Du G, Li JZ, Yang S, Ye J, Yao H, Zhang Y, Xue B, Li Q, Yang H, Wen Z, Li P (2008) Up-regulation of mitochondrial activity and acquirement of brown adipose tissuelike property in the white adipose tissue of fsp27 deficient mice. PLoS ONE 3:e2890

18. Ye J, Li JZ, Liu Y, Li X, Yang T, Ma X, Li Q, Yao Z, Li P (2009) Cideb, an ER- and lipid droplet-associated protein, mediates VLDL lipidation and maturation by interacting with apolipoprotein B. Cell Metab 9:177-190

19. Li JZ, Ye J, Xue B, Qi J, Zhang J, Zhou Z, Li Q, Wen Z, Li P (2007) Cideb regulates diet-induced obesity, liver steatosis, and insulin sensitivity by controlling lipogenesis and fatty acid oxidation. Diabetes 56:2523-2532

20. Yao M, Huang Y, Shioi K, Hattori K, Murakami T, Nakaigawa N, Kishida T, Nagashima Y, Kubota Y (2007) Expression of adipose differentiation-related protein: a predictor of cancerspecific survival in clear cell renal carcinoma. Clin Cancer Res 13:152-160

21. Thoenes W, Storkel S, Rumpelt HJ (1986) Histopathology and classification of renal cell tumors (adenomas, oncocytomas and carcinomas). The basic cytological and histopathological elements and their use for diagnostics. Pathol Res Pract 181: $125-143$

22. Delahunt B, Bethwaite PB, Thornton A (1997) Prognostic significance of microscopic vascularity for clear cell renal cell carcinoma. Br J Urol 80:401-404

23. Sabo E, Boltenko A, Sova Y, Stein A, Kleinhaus S, Resnick MB (2001) Microscopic analysis and significance of vascular architectural complexity in renal cell carcinoma. Clin Cancer Res 7:533-537

24. Qi J, Gong J, Zhao T, Zhao J, Lam P, Ye J, Li JZ, Wu J, Zhou HM, Li P (2008) Downregulation of AMP-activated protein kinase by Cidea-mediated ubiquitination and degradation in brown adipose tissue. EMBO J 27:1537-1548

25. Zhou L, Xu L, Ye J, Li D, Wang W, Li X, Wu L, Wang H, Guan F, Li P (2012) Cidea promotes hepatic steatosis by sensing dietary fatty acids. Hepatology 56:95-107

26. Yonezawa T, Kurata R, Kimura M, Inoko H (2011) Which CIDE are you on? apoptosis and energy metabolism. Mol Biosyst 7:91-100

27. O'Toole KM, Brown M, Hoffmann P (1993) Pathology of benign and malignant kidney tumors. Urol Clin North Am 20:193-205

28. Yao M, Tabuchi H, Nagashima $Y$, Baba M, Nakaigawa N, Ishiguro $\mathrm{H}$, Hamada $\mathrm{K}$, Inayama $\mathrm{Y}$, Kishida $\mathrm{T}$, Hattori $\mathrm{K}$, Yamada-Okabe H, Kubota Y (2005) Gene expression analysis of renal carcinoma: adipose differentiation-related protein as a potential diagnostic and prognostic biomarker for clear-cell renal carcinoma. J Pathol 205:377-387

29. Fuhrman SA, Lasky LC, Limas C (1982) Prognostic significance of morphologic parameters in renal cell carcinoma. Am J Surg Pathol 6:655-663

30. Tun HW, Marlow LA, von Roemeling CA, Cooper SJ, Kreinest P, Wu K, Luxon BA, Sinha M, Anastasiadis PZ, Copland JA (2010) Pathway signature and cellular differentiation in clear cell renal cell carcinoma. PLoS One 5:e10696 